\title{
Method of increasing yield indicators of rice varieties in process of seed production
}

\author{
N. A. Ochkas ${ }^{1,3}, Y u . K$. Goncharova ${ }^{1,3, *}, O . A$. Bragina ${ }^{1,3}$, and K.S. Krikun ${ }^{2}$ \\ ${ }^{1}$ FGBNU "Federal Research Center for Rice", Belozerny, 3, 350921 Krasnodar, RF \\ ${ }^{2}$ FGBOU VO "Kuban State Agrarian University named after I.T. Trubilin ", 350044 Krasnodar, RF \\ ${ }^{3} \mathrm{OOO}$ "Aratai", "Skolkovo", 143026 Moscow, RF
}

\begin{abstract}
The paper describes a method for creating new and increasing the yield of existing varieties based on analysis variability elements of rice varieties yield structure under influence of environmental conditions. Seeding rates are used as a source of variability. Following trait are analyzed: seeds field germination, survival plants before harvesting, total tillering of plants, realization of total tillering, graininess of panicle, fertility of spikelets, weight of 1000 grains. Based on analysis, through onnections conjugated elements, the optimal values of elements structure of yield are determined, at which it takes the maximum value. Based on a set of optimal values, theoretical model of studied rice variety is being developed. Then, according to panicles selected in variety, single-row plots are sown for further propagation, rows with parameters of the yield structure elements set same with model of variety are selected, which makes it possible to increase the yield of Mavr rice variety by 39.18 centners / ha or $45.61 \%$.
\end{abstract}

\section{Introduction}

The continuing growth of world's population requires the introduction of new breeding technologies into practice, capable of creating in 30 years varieties that are $70 \%$ more productive than existing ones [1]. At the same time, it was noted that many crops are close to their yield plateau and further improvement by traditional breeding methods is problematic $[2,3]$. Methods associated with the fixation of heterotic effect, the use of genes of wide compatibility, an increase in photosynthetic potential of plants, tissue culture technologies, or induced mutagenesis are considered promising $[4,5,6]$.

Recently, the methods of transgenic selection and genomic editing have been rapidly developing; at the same time, their potential danger to humanity has been noted [7-9]. However, many works have shown the potential of traditional breeding, which has not yet been fully realized $[10,11,12]$. In our work, we present a method for creating new and increasing the yield of existing varieties that does not require the introduction of foreign DNA or the effects of mutagens and, therefore, is safe. The method does not require expensive equipment, at the same time its efficiency, according to our data, in some cases exceeds $40 \%$.

\footnotetext{
* Corresponding author: yuliya goncharova 20@mail.ru
} 


\section{Materials and methods}

Seeds of the studied variety are sown in single-row plots with a total area of $3 \mathrm{~m}^{2}$ with a cassette seeder; plants from the entire plot are manually harvested into sheaves. Modeling of changing environmental conditions, in order to increase the variation of elements of yield structure, is carried out by different rates of sowing rice seeds at the rate of: $1,3,5,7$, 9 and 11 million grains per 1 hectare. When shoots appear, they are counted on the plot and recalculated per $1 \mathrm{~m}^{2}$.

Plant from plot are analyzed in laboratory conditions, where number of plants, shoots and panicles preserved before harvesting is counted, number of spikelets, grains and their weight are determined for 25 plants.

Based on analysis of results, germination rate is calculated (the ratio number of seedlings to the sown seeds); survival (the ratio plants preserved before harvesting to number of seedlings obtained); total bushiness of plants (the ratio of number of shoots to number of plants); realization of plants bushiness (the ratio number of panicles to number of shoots); spikeiness (the ratio of number of spikelets to number of panicles); fertility ( ratio of grains number to number of spikelets) and mass of 1000 grains (the ratio of grain mass to their number multiplied by 1000).

The grain yield is calculated by formula:

$$
Y=\frac{S * S g * S v^{*} B u * P b^{*} N u * F * M}{100}
$$

Where: Y - yield, c / ha;

$\mathrm{S}$ - is seeding rate of seeds;

Sh - seed germination;

Sv - survival rate of seedlings;

$\mathrm{Bu}$ - bushiness of plants;

$\mathrm{Pb}$ - realization of bushiness of plants;

$\mathrm{Nu}$ - spikeiness of the panicle;

F - spikelet fertility;

$\mathrm{M}$ - is mass of 1000 grains;

100 - conversion factor in centners / ha.

Agricultural technology is generally accepted in experience.

Mathematical processing of the results obtained was carried out in the programs Statistica 10.0 and Microsoft Excel. 2010 [14-15].

\section{Results and discussion}

As an example, to demonstrate the principle of improving yield indicators, we show the calculation on the Mavr rice variety with a colored grain pericarp.

The results of analyzes are entered into the table of initial data, from which it can be concluded that maximum grain yield of rice variety Mavr is $85.91 \mathrm{c} /$ ha is formed at a seeding rate 5 million grains per 1 ha, with an average $72.74 \mathrm{c} /$ ha according to options. Table 1. 
Table 1. Initial data of the result of the analysis of yield and elements of its structure of the variety Mavr.

\begin{tabular}{|c|c|c|c|c|c|c|c|c|c|}
\hline \multirow[b]{2}{*}{ № } & \multicolumn{8}{|c|}{ Yield structure elements } & \multirow[b]{2}{*}{$\begin{array}{c}\text { Prod } \\
\text { ucti } \\
\text { vity, } \\
\text { c / } \\
\text { ha }\end{array}$} \\
\hline & $\begin{array}{c}\text { So } \\
\text { wi } \\
\text { ng } \\
\text { rat } \\
\text { e }\end{array}$ & $\begin{array}{c}\text { Ger } \\
\text { min } \\
\text { atio } \\
\mathrm{n} \\
\text { rate }\end{array}$ & $\begin{array}{l}\text { Surviv } \\
\text { al rate }\end{array}$ & $\begin{array}{c}\text { Toug } \\
\text { hnes } \\
\text { s }\end{array}$ & $\begin{array}{l}\text { Imple } \\
\text { mentat } \\
\text { ion of } \\
\text { tillerin } \\
\mathrm{g}\end{array}$ & $\begin{array}{l}\text { Headi } \\
\text { ng } \\
\text { rate }\end{array}$ & $\begin{array}{c}\text { Ferti } \\
\text { lity }\end{array}$ & $\begin{array}{c}\text { Weig } \\
\mathrm{ht} \\
1000 \\
\text { grains }\end{array}$ & \\
\hline 1 & 1 & $\begin{array}{c}0,9 \\
0\end{array}$ & 0,67 & 4,33 & 1,00 & $\begin{array}{c}131,5 \\
0\end{array}$ & 0,81 & 24,67 & $\begin{array}{c}67,9 \\
9\end{array}$ \\
\hline 2 & 3 & $\begin{array}{c}0,8 \\
0 \\
\end{array}$ & 0,42 & 4,10 & 0,93 & $\begin{array}{c}106,8 \\
0 \\
\end{array}$ & 0,78 & 25,26 & $\begin{array}{c}80,0 \\
7 \\
\end{array}$ \\
\hline 3 & 5 & $\begin{array}{c}0,7 \\
4 \\
\end{array}$ & 0,49 & 3,06 & 0,96 & 82,70 & 0,80 & 24,38 & $\begin{array}{c}85,9 \\
1 \\
\end{array}$ \\
\hline 4 & 7 & $\begin{array}{c}0,6 \\
7\end{array}$ & 0,47 & 2,18 & 0,96 & 74,90 & 0,81 & 26,12 & $\begin{array}{c}72,4 \\
5\end{array}$ \\
\hline 5 & 9 & $\begin{array}{c}0,5 \\
5 \\
\end{array}$ & 0,55 & 2,85 & 0,91 & 51,60 & 0,77 & 25,18 & $\begin{array}{c}69,7 \\
9 \\
\end{array}$ \\
\hline 6 & 11 & $\begin{array}{c}0,4 \\
7\end{array}$ & 0,39 & 3,07 & 0,80 & 64,40 & 0,83 & 22,87 & $\begin{array}{c}60,2 \\
3 \\
\end{array}$ \\
\hline $\begin{array}{c}\text { Avera } \\
\text { ge }\end{array}$ & $\begin{array}{c}6,0 \\
0\end{array}$ & $\begin{array}{c}0,6 \\
9\end{array}$ & 0,50 & 3,26 & 0,93 & 85,32 & 0,80 & 24,75 & $\begin{array}{c}72,7 \\
4\end{array}$ \\
\hline $\begin{array}{l}\text { Mini } \\
\text { mum }\end{array}$ & $\begin{array}{c}1,0 \\
0 \\
\end{array}$ & $\begin{array}{c}0,4 \\
7 \\
\end{array}$ & 0,39 & 2,18 & 0,80 & 51,60 & 0,77 & 22,87 & $\begin{array}{c}60,2 \\
3 \\
\end{array}$ \\
\hline $\begin{array}{l}\text { Maxi } \\
\text { mum }\end{array}$ & $\begin{array}{l}11, \\
00\end{array}$ & $\begin{array}{c}0,9 \\
0\end{array}$ & 0,67 & 4,33 & 1,00 & $\begin{array}{c}131,5 \\
0\end{array}$ & 0,83 & 26,12 & $\begin{array}{c}85,9 \\
1 \\
\end{array}$ \\
\hline
\end{tabular}

When calculating yield through average parameters options elements of its structure according to the above formula is:

$$
y=\frac{S^{*} S g^{*} S v^{*} B u^{*} P b^{*} N u^{*} F^{*} M}{100}=\frac{6 * 0,69 * 0,5 * 3,26 * 0,93 * 85,32 * 0,8 * 24,75}{100}=106,02 c / h a
$$

which is $20.11 \mathrm{c} /$ ha higher than the best option by experience. Determination of yield through the maximum values of its elements according to variants of experiment shows: $\mathrm{Y}$ $=818.79 \mathrm{c} /$ ha, through the minimum values $-\mathrm{Y}=2.9 \mathrm{c} /$ ha. The researcher should not be confused by such figures because they were obtained without taking into account the conjugation of yield structure elements with each other, the elimination of this drawback is achieved when developing a variety model.

\subsection{Developing a variety model}

To develop a variety model, it is first necessary to determine all relationships between elements of yield structure with each other. For example, to determine relationship between seeding rate of seeds and their germination on graph of the polynomial dependence of the second degree, we determine equation and reliability of approximation coefficient according to data in Table 1, Figure 1. 


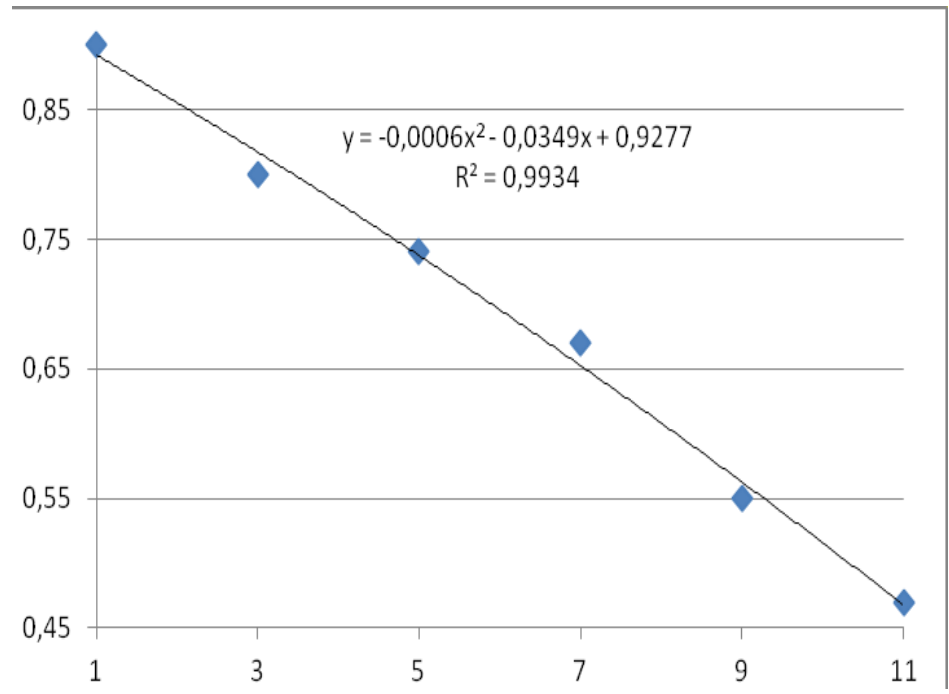

Fig. 1. Relationship of the seeding rate of seeds with their germination, rice varieties Mavr. Y-axis germination rate. $\mathrm{X}$-axis is seeding rate millions seeds per hectare.

Relationship between seeding rate of seeds, rice varieties Mavr, with their germination is described by equation: $\mathrm{y}=-0.0006 \mathrm{x} 2-0.0349 \mathrm{x}+0.9277$ where: $\mathrm{y}$ - field germination of seeds; $\mathrm{x}$ - is the seeding rate of seeds, with accuracy of approximation coefficient $\mathrm{R}^{2}=$ 0.9934 , which meets our requirements.

The graph clearly shows that with an increase in seeding rate of seeds, their field germination decreases.

Having determined connections of seeding rate with the rest of elements of yield structure, it was found that they are described by following equations: with survival rate of seedlings $\mathrm{y}=0.0022 \mathrm{x} 2-0.0406 \mathrm{x}+0.636$; bushiness of plants $\mathrm{y}=0.0406 \mathrm{x} 2-0.6438 \mathrm{x}+$ 5.1919; realization bushiness of plants $\mathrm{y}=-0.0022 \mathrm{x} 2+0.0121 \mathrm{x}+0.9614$; spikeiness of panicle $\mathrm{y}=0.8513 \mathrm{x} 2-17.486 \mathrm{x}+149.65$; spikelet fertility $\mathrm{y}=0.0009 \mathrm{x} 2-0.0092 \mathrm{x}+0.8131$ and 1000 grain weight $\mathrm{y}=-0.0658 \times 2+0.6823 \mathrm{x}+23.79$.

Substituting sequentially in the obtained equations value of seeding rate within the variation of experiment, we determine the values elements of yield structure and through their product divided by 100 (the formula for determining yield), we establish yield of rice grain Mavr variety at these values, Figure 2. 


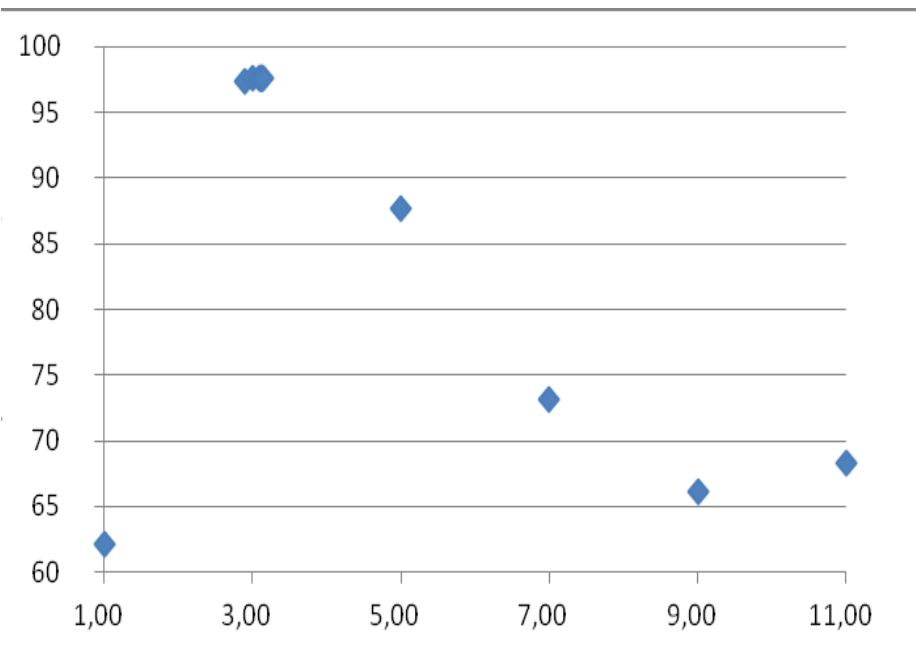

Fig. 2. Productivity of Mavr rice grain at different seeding rates. Y-axis yield. $\mathrm{X}$-axis is the seed rate.

The figure shows that maximum grain yield rice variety Mavr is formed at seeding rate of seeds close to 3 million per 1 ha. Using the trial and error method, we refine this indicator as shown in Table 2.

Table 2. An example of calculating the optimal seeding rate for rice varieties Mavr.

\begin{tabular}{|c|c|c|c|c|c|c|c|c|}
\hline \multirow{2}{*}{$\begin{array}{c}\text { Seedin } \\
\text { g rate }\end{array}$} & $\begin{array}{c}\text { Germ } \\
\text { inatio } \\
\text { n rate }\end{array}$ & $\begin{array}{c}\text { Surviv } \\
\text { al rate }\end{array}$ & Bushiness & $\begin{array}{c}\text { Realizatio } \\
\text { n of } \\
\text { bushiness }\end{array}$ & $\begin{array}{c}\text { Spikeines } \\
\text { s }\end{array}$ & $\begin{array}{c}\text { Fertilit } \\
\text { y }\end{array}$ & $\begin{array}{c}\text { Weight } \\
1000 \\
\text { grains }\end{array}$ & Yield \\
\hline 1,00 & 0,89 & 0,60 & 4,59 & 0,97 & 133,02 & 0,80 & 24,41 & 62,088 \\
\hline 2,90 & 0,82 & 0,54 & 3,67 & 0,98 & 106,10 & 0,79 & 25,22 & 97,390 \\
\hline 3,00 & 0,82 & 0,53 & 3,63 & 0,98 & 104,85 & 0,79 & 25,24 & 97,559 \\
\hline 3,09 & 0,81 & 0,53 & 3,59 & 0,98 & 103,75 & 0,79 & 25,27 & 97,624 \\
\hline 3,10 & 0,81 & 0,53 & 3,59 & 0,98 & 103,62 & 0,79 & 25,27 & 97,627 \\
\hline 3,11 & 0,81 & 0,53 & 3,58 & 0,98 & 103,50 & 0,79 & 25,28 & 97,628 \\
\hline $\mathbf{3 , 1 2}$ & $\mathbf{0 , 8 1}$ & $\mathbf{0 , 5 3}$ & $\mathbf{3 , 5 8}$ & $\mathbf{0 , 9 8}$ & $\mathbf{1 0 3 , 3 8}$ & $\mathbf{0 , 7 9}$ & $\mathbf{2 5 , 2 8}$ & $\mathbf{9 7 , 6 2 9}$ \\
\hline 3,13 & 0,81 & 0,53 & 3,57 & 0,98 & 103,26 & 0,79 & 25,28 & 97,628 \\
\hline 3,14 & 0,81 & 0,53 & 3,57 & 0,98 & 103,14 & 0,79 & 25,28 & 97,627 \\
\hline 5,00 & 0,74 & 0,49 & 2,99 & 0,97 & 83,50 & 0,79 & 25,56 & 87,684 \\
\hline 7,00 & 0,65 & 0,46 & 2,67 & 0,94 & 68,96 & 0,79 & 25,34 & 73,162 \\
\hline 9,00 & 0,57 & 0,45 & 2,69 & 0,89 & 61,23 & 0,80 & 24,60 & 66,170 \\
\hline 11,00 & 0,47 & 0,46 & 3,02 & 0,83 & 60,31 & 0,82 & 23,33 & 68,294 \\
\hline Maxi & & & & & & & & 9 \\
mum & & & & & & & & 97,629 \\
\hline
\end{tabular}

As can be seen from the table, the maximum yield $97.629 \mathrm{c} /$ ha is formed at seeding rate 3.12 million seeds per 1 ha, therefore, this seeding rate for Mavr variety is considered optimal.

Next, we establish optimal values remaining elements of yield structure, for example, 0.81 with a yield of $99.44 \mathrm{c} /$ ha is considered optimal for seed germination. To obtain the desired germination, it is necessary to sow with a seeding rate of 3.19 million seeds per 1 ha, while: the survival rate of seedlings will be at level 0.53 ; bushiness of plants - 3.58; realization bushiness of plants - 0.98 ; panicle spikeiness 103.68 ; spikelet fertility 0.79 and 1000 grain weight 25.23 table 3 .

Table 3. Productivity of grain of rice variety Mavr when optimizing the elements of its structure. 


\begin{tabular}{|c|c|c|c|c|c|c|c|c|c|}
\hline $\begin{array}{c}\text { Structure } \\
\text { elements }\end{array}$ & $\begin{array}{c}\text { See } \\
\mathrm{d} \\
\text { ing } \\
\text { rate }\end{array}$ & $\begin{array}{c}\text { min } \\
\text { atin } \\
\text { m } \\
\text { abili } \\
\text { ty }\end{array}$ & $\begin{array}{c}\text { Surv } \\
\text { val } \\
\text { Bus } \\
\text { hine } \\
\text { ss }\end{array}$ & $\begin{array}{c}\text { Bus } \\
\text { hin } \\
\text { ess }\end{array}$ & $\begin{array}{c}\text { Implemen } \\
\text { tation of } \\
\text { bushiness }\end{array}$ & $\begin{array}{c}\text { Spike } \\
\text { iness }\end{array}$ & $\begin{array}{c}\text { Fert } \\
\text { il } \\
\text { ity }\end{array}$ & $\begin{array}{c}\text { Weight } \\
\text { of 1000 } \\
\text { grains }\end{array}$ & $\begin{array}{c}\text { Yield, } \\
\text { centne } \\
\text { r ha }\end{array}$ \\
\hline $\begin{array}{c}\text { Norm } \\
\text { seeding }\end{array}$ & $\mathbf{3 , 1 2}$ & 0,81 & 0,53 & $\begin{array}{c}3,5 \\
8\end{array}$ & 0,98 & $\begin{array}{c}103,3 \\
8\end{array}$ & 0,79 & 25,28 & 97,63 \\
\hline Germination & 3,19 & $\mathbf{0 , 8 1}$ & 0,53 & $\begin{array}{c}3,5 \\
8\end{array}$ & 0,98 & $\begin{array}{c}103,6 \\
8\end{array}$ & 0,79 & 25,23 & 99,44 \\
\hline Survival & $\mathbf{3 , 2 0}$ & $\mathbf{0 , 8 1}$ & $\mathbf{0 , 6 3}$ & $\begin{array}{c}\mathbf{3 , 7} \\
\mathbf{0}\end{array}$ & $\mathbf{0 , 9 9}$ & $\begin{array}{c}\mathbf{1 0 5 , 4} \\
\mathbf{2}\end{array}$ & $\mathbf{0 , 7 9}$ & $\mathbf{2 5 , 0 7}$ & $\mathbf{1 2 5 , 0 9}$ \\
\hline Bushiness & 4,26 & 0,75 & 0,52 & $\begin{array}{c}\mathbf{3 , 9} \\
\mathbf{5}\end{array}$ & 0,93 & $\begin{array}{c}101,3 \\
1\end{array}$ & 0,80 & 24,32 & 119,01 \\
\hline $\begin{array}{c}\text { Implementation } \\
\text { of bushiness }\end{array}$ & 3,29 & 0,81 & 0,57 & $\begin{array}{c}3,5 \\
6\end{array}$ & $\mathbf{0 , 9 8}$ & $\begin{array}{c}106,1 \\
5\end{array}$ & 0,80 & 24,98 & 111,99 \\
\hline Colosity & 3,36 & 0,81 & 0,46 & $\begin{array}{c}3,8 \\
8\end{array}$ & 0,95 & $\begin{array}{c}\mathbf{1 0 4 , 2} \\
\mathbf{0}\end{array}$ & 0,80 & 24,47 & 94,01 \\
\hline Fertility & 5,02 & 0,74 & 0,50 & $\begin{array}{c}3,3 \\
1\end{array}$ & 0,95 & 96,48 & $\mathbf{0 , 8 1}$ & 24,73 & 113,82 \\
\hline $\begin{array}{c}\text { Weight of } 1000 \\
\text { grains }\end{array}$ & 5,10 & 0,71 & 0,53 & $\begin{array}{c}3,7 \\
6\end{array}$ & 0,94 & 93,63 & 0,81 & $\mathbf{2 4 , 0 5}$ & 122,53 \\
\hline
\end{tabular}

After analyzing yield of rice grain Mavr variety, when optimizing elements of its structure, it was found that the maximum yield $125.09 \mathrm{c} /$ ha is formed when optimizing the survival rate of seedlings 0.63 , which exceeds yield of best option in experiment by $39.18 \mathrm{c}$ / ha or $45.61 \%$, therefore, values of remaining elements associated with this indicator can be taken as a theoretical model of variety.

Model of Mavr variety: seeding rate 3.2 million seeds per hectare, their germination rate should be at level 0.81 ; seedling survival - 0.63 ; bushiness of plants - 3.7 ; realization bushiness of plants - 0.99; panicle spike - 105.42; spikelet fertility - 0.79; mass of 1000 grains - 25.07; with a yield $-125.09 \mathrm{c} /$ ha.

In other words, at a seeding rate of 3.2 million grains per 1 ha, per $1 \mathrm{~m}^{2}$, it is necessary to obtain: 259 seedlings of which 163 plants will remain before harvesting, which will form 603 shoots and develop 597 panicles with 105 spikelets each of which will produce 84 grain total weight $2.1 \mathrm{~g}$.

\subsection{Improving the yield indicators of the Mavr rice variety:}

1. Intravarietal mass breeding panicles is carried out.

2. With a cassette seeder panicles, are sown with single-row plots with a seeding rate 3.2 million per 1 ha.

3. For further work, plots are selected according to the parameters of yield structure elements set by variety model.

4. Next year, seeds from selected plots are sown by plots, with the same seeding rate of 3.2 million per $1 \mathrm{ha}$, the plant are selected, which are inherited parameters of yields structure elements laid down by model, and then begining to reproduce the improved variety.

\section{Conclusions}


The selection according to parameters set of model elements of yield structure in the process of seed production allows increasing rice grain yield Mavr variety up to $125 \mathrm{c} / \mathrm{ha}$, which is $39.18 \mathrm{c} /$ ha or $45.61 \%$ higher than best variant in experiment.

\section{Acknowledgments}

This work was carried out with the financial support of the Russian Science Foundation No. 19-16-00064.

\section{References}

1. Food and agriculture organization of the United Nations, https:// www.fao.org

2. Yu. K. Goncharova, Russian J. of Developmental Biology, 45 (2014)

3. L. Ge, H. Chen, J.F. Jiang, Y. Zhao, M.L. Xu, Y.Y. Xu, et al., Plant Physiology, 135 (2004)

4. Yu. K. Goncharova, S.V. Gontcharov, E.E. Chicharova, Russian J. of Genetics, 54 (2018)

5. Yu. K. Goncharova, S.A. Vereshchagina, S.V. Gontcharov, Plant Cell Biotechnology and Molecular Biology, 20 (2019)

6. Y. Rhee, R.S. Sekhon, S. Chopra, S. Kaeppler, Genetics, 186, 3 (2010)

7. M. Lusser, C. Paris, D. Plan, E. Rodriguez-Cerezo, Nature Biotechnology, 30 (2012)

8. H. Zhao, J.D. Wolt, Emerging Topics in Life Sciences, 1, 2 (2017)

9. A. Whelan, M. Lema, GM Crops \& Food, 6, 4 (2015)

10. M. Lema, Poster presented at the Int. Symposium on the Biosafety of Genetically Modified Organisms (ISBGMO14) (2017)

11. H.D. Jones, Nature Plants, 8, 1 (2015)

12. T. Laaninen, New plant-breeding techniques, http://www.europarl.europa.eu

13. V.A. Dragavtsev, J. of Technical Physics, 90, 10 (2020)

14. A. Kh. Sheudzhen, O. A. Gutorova, E.V. Shein, V. A. Romanenkov, IOP Conference Se ries, 368 (2019)

15. V.I. Lapshin, V.V. Yakovenko, S.N. Shcheglov, BIO Web of Conferences (2020) 